\title{
Deracemization of sec-Alcohols through Sequential Application of C. albicans and Ketoreductases
}

\author{
Fábio D. Nasário, ${ }^{a}$ Paulo J. S. Moran ${ }^{\circledR a}$ and José Augusto R. Rodrigues ${ }^{\circledR *, a}$ \\ ${ }^{a}$ Departamento de Química Orgânica, Instituto de Química, Universidade Estadual de Campinas, \\ 13084-971 Campinas-SP, Brazil
}

\begin{abstract}
A biocatalytic cascade process was developed using immobilized cells of the wild type yeast Candida albicans CCT 0776 in calcium alginate beads and a commercially available ketoreductase. The aim was to promote deracemization by stereoinversion of ( \pm )-1-arylethanols in high substrate concentration (above $100 \mathrm{mmol} \mathrm{L}^{-1}$ ) to prepare the $(R)$-enantiomers of the alcohols (90-99\%), with a high enantiomeric excess (83-99\%) after 2 to 19 h. The $(R)$-1-(3-methoxyphenyl)ethanol, with $70 \%$ yield and $91 \%$ ee, obtained after $5 \mathrm{~h}$ was used to prepare $(S)$-1-(3-methoxyphenyl)-ethylamine with $60 \%$ yield and $91 \%$ ee after two steps, a key intermediate in the synthesis of $(S)$-rivastigmine.
\end{abstract}

Keywords: oxidative kinetic resolution, deracemization, stereoinversion, ketoreductase, alcohol dehydrogenase

\section{Introduction}

Biocatalytic processes using whole cells of microorganisms or isolated enzymes are recognized as useful tools in the preparation of important enantiopure compounds such as chiral alcohols or amines. These compounds are used as building blocks to synthesize natural products, pharmaceuticals, and agricultural chemicals ${ }^{1-5}$ such as $(S)$-rivastigmine, ${ }^{6}$ taxol, ${ }^{7}(S)$-fluoxetine, ${ }^{8}$ betalactams antibiotics, ${ }^{9,10}$ lipid $\mathrm{A}^{11}$ and L-carnitine ${ }^{12}$ and $(S)$-beta-blockers ${ }^{13}$ as propranolol, metoprolol and $(S)$-carvedilol (Figure 1).

The use of enzymes was restricted to selective modification of racemic mixtures in kinetic resolution (KR) procedures, resulting in a maximum $50 \%$ yield of the enantiopure product ${ }^{14-20}$ or reduction of prochiral compounds. ${ }^{21-23}$ In recent years, multi-enzymatic methodologies have emerged as useful tools in the preparation of chiral compounds with a theoretical 100\% yield. This is because enzymes largely operate under similar conditions, such as neutral $\mathrm{pH}$ and moderate temperature, and typically exhibit high substrate specificity. ${ }^{2,24,25}$

Oxidoreductases, such as alcohol dehydrogenases (ADHs, also known as ketoreductases (KREDs)), depend on their (costly) nicotinamide cofactor $\left(\mathrm{NAD}(\mathrm{P})^{+}\right)$to catalyze enantioselective reduction of ketones (and

*e-mail: jaugusto@iqm.unicamp.br

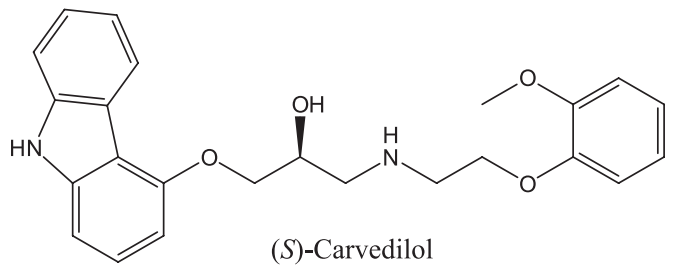<smiles>C[C@@H](c1cccc(OC(=O)N(C)C)c1)N(C)C</smiles>

(S)-Rivastigmine<smiles>CNC[C@H](Oc1ccc(C(F)(F)F)cc1)c1ccccc1</smiles>

$(S)$-Fluoxetine
Figure 1. Examples of drugs derived from chiral secondary alcohol precursors.

aldehydes), as well as the stereoselective oxidation of alcohols. ${ }^{1,26,27}$ The use of ADHs to promote deracemization of racemic secondary alcohols, in substrate concentration range of 25-80 $\mathrm{mmol} \mathrm{L}^{-1}$, has been studied using a single microorganism, ${ }^{28-32}$ a consortium of two microorganisms, ${ }^{33-35}$ whole cells of a natural or recombinant biocatalyst and an isolated $\mathrm{ADH},{ }^{1,36}$ chemo-enzymatic ${ }^{6,37}$ and enzymatic processes $^{38,39}$ with a view to obtaining enantiopure compounds exhibiting a $100 \%$ maximum yield, since racemic substrates are more readily available starting materials than prochiral substrates. ${ }^{24}$ 
Biocatalytic deracemization of secondary alcohols, which means conversion of a racemate into an enantiopure compound mediated by enzymes, generally occurs via two distinct mechanisms: stereoinversion or cyclic deracemization. Deracemization via stereoinversion involves the stereoselective oxidation of an enantiomer into an intermediate ketone, which is subsequently reduced to the alcohol, with the opposite configuration to the enantiomer oxidized, obtaining a single enantiomer at the end of the process. ${ }^{40}$ Cyclic deracemization systems, on the other hand, use a low(non)-selective irreversible reaction, such as partially selective reduction of a prochiral ketone, combined with stereospecific oxidation of an enantiomer. Thus, the enantiomer that is not oxidized accumulates after several cycles. ${ }^{41-43}$ In this respect, the yeast Candida sp. is widely reported as an important source of oxidoreductases and mediates the synthesis of a broad range of chiral compounds. ${ }^{44}$ In a previous study, we reported deracemization of $( \pm)$-1-phenylethanol via stereoinversion, initially using a sequential process with Candida albicans and Lactobacillus brevis to prepare the $(R)$-enantiomer. Inverting the sequence of these microorganisms produces an enantioenriched antipode. ${ }^{14}$

Here, we report efficient deracemization via stereoinversion of $( \pm)$-1-arylethanols, in high substrate concentration (above $100 \mathrm{mmol} \mathrm{L}^{-1}$ ), using a cascade process with Candida albicans CCT 0776 and different commercial ketoreductases to produce enantioenriched $(R)$-alcohols. Additionally, we demonstrate a practical application of this deracemization procedure and the value of these compounds in synthesizing the key intermediate drug $(S)$-rivastigmine, used to treat Parkinson's and Alzheimer's disease. ${ }^{45}$

\section{Experimental}

\section{General methods}

The ketones 2 a-i and ADH from Parvibaculum lavamentivorans (ADH-PL) were purchased from Sigma-Aldrich ${ }^{\circledR}$ and the KREDs from Codexis ${ }^{\circledR}$. All the other commercial reagents and solvents were purchased from Sigma-Aldrich ${ }^{\circledR}$ at the highest purity available and used as received. Nuclear magnetic resonance (NMR) spectra were recorded in an Avance spectrometer at 400 ( ${ }^{1} \mathrm{H}$ NMR) and $100 \mathrm{MHz}\left({ }^{13} \mathrm{C}\right.$ NMR). Chemical shifts were reported in parts per million (ppm) and coupling constants $(J)$ in hertz $(\mathrm{Hz})$. Optical rotation was measured using a Carl Weiss POLAMAT A polarimeter. Gas chromatography (GC) analyses were performed in an Agilent ${ }^{\circledR} 6890$ Series GC system equipped with a J\&W Scientific DB1 silica capillary column $(30 \mathrm{~m} \times 0.25 \mathrm{~mm}$ i.d. $\times 0.25 \mathrm{~m}$ film thickness), using helium as the carrier gas $\left(0.9 \mathrm{~mL} \mathrm{~min}^{-1}\right)$ and a split ratio of 1:50. The injector and detector temperatures were maintained at 230 and $280{ }^{\circ} \mathrm{C}$, respectively. Column temperature was kept at $60{ }^{\circ} \mathrm{C}$ for $1 \mathrm{~min}$, increased to $230{ }^{\circ} \mathrm{C}$ at a rate of $30^{\circ} \mathrm{C} \mathrm{min}^{-1}$, raised again to $280{ }^{\circ} \mathrm{C}$ at a rate of $25^{\circ} \mathrm{C} \mathrm{min}^{-1}$ and then maintained constant for $2 \mathrm{~min}$. One microliter of a $0.3 \mathrm{mg} \mathrm{mL}^{-1}$ solution of the compound or extracted reaction aliquots in ethyl acetate was injected. Chiral GC flame ionization detection (FID) analysis was conducted in an Agilent ${ }^{\circledR} 6850$ Series GC system equipped with a Hydrodex ${ }^{\circledR}-\beta$-3P chiral capillary column $(25 \mathrm{~m} \times 0.25 \mathrm{~mm} \times 0.25 \mathrm{~m})$. The carrier gas was hydrogen $\left(1 \mathrm{~mL} \mathrm{~min}^{-1}\right)$ and injector and detector temperatures were set at 200 and $220^{\circ} \mathrm{C}$, respectively. Chiral high-performance liquid chromatography (HPLC) analysis was carried out in an Agilent ${ }^{\circledast}$ Technologies 1200 series system, using a $15 \mathrm{~cm} \times 2.1 \mathrm{~mm} \times 5 \mu \mathrm{m}$ Supelco Astec cellulose DMP column obtained from Sigma-Aldrich ${ }^{\circledR}$, with a UV-Vis detector. Thin layer chromatography (TLC) analysis was performed using aluminum plates coated with F254 nm silica gel. The C. albicans CCT 0776 yeast strain was purchased from the André Tosello Research Foundation (Campinas, São Paulo State, Brazil) and stored at ultra-low temperature $\left(-80^{\circ} \mathrm{C}\right)$ in $20 \%$ glycerol.

Growth conditions of $C$. albicans, cell immobilization, synthesis, characterization of the racemic alcohols $( \pm)-\mathbf{1 a}-\mathbf{i}$ and isolated products $(R)-\mathbf{1 a - i}$ obtained via biocatalysis were reported in a previous study. ${ }^{14}$

Screening of ketoreductases: reduction of acetophenone (2a)

The ketoreductases obtained from Codexis, as a lyophilized pounder with $40-70 \%$ of the enzyme, were screened in accordance with the producer's protocol. Approximately $10 \mathrm{mg}$ of KREDs 1-5 (Table 1, entries 1-5) were weighed out into separate labelled vials, which were added with $1 \mathrm{~mL}$ of a fresh KRED Recycle Mix N solution (containing $50 \mathrm{mmol} \mathrm{L}^{-1}$ of $\mathbf{2 a}, 250 \mathrm{mmol} \mathrm{L}^{-1}$ of potassium phosphate, $2 \mathrm{mmol} \mathrm{L}^{-1}$ of magnesium sulfate, $1.1 \mathrm{mmol} \mathrm{L}^{-1}$ of $\mathrm{NAD}^{+}, 1.1 \mathrm{mmol} \mathrm{L}^{-1}$ of $\mathrm{NADP}^{+}$, $80 \mathrm{mmol} \mathrm{L}^{-1}$ of D-glucose and $10 \mathrm{U} \mathrm{mL}^{-1}$ of GDH (glucose dehydrogenase), $\mathrm{pH}$ 7.0). The reaction was mixed at $30^{\circ} \mathrm{C}$ and $180 \mathrm{rpm}$ for $19 \mathrm{~h}$. An aliquot of $250 \mu \mathrm{L}$ of the reaction mixture was extracted with $500 \mu \mathrm{L}$ of ethyl acetate and dried with sodium sulfate. Conversion and enantiomeric excess were measured by GC-mass spectrometry (MS) and GC-FID. For ADH-PL (Table 1, entry 25), $15 \mu \mathrm{L}$ of enzyme suspension was used, while for KREDs 6-24 (Table 1, entries 6-24), $10 \mathrm{mg}$ of each enzyme was weighed out into separate labelled vials, which were added with 
$0.9 \mathrm{~mL}$ of KRED Recycle Mix P (containing $125 \mathrm{mmol} \mathrm{L}^{-1}$ of potassium phosphate, $1.25 \mathrm{mmol} \mathrm{L}^{-1}$ magnesium sulfate, $1 \mathrm{mmol} \mathrm{L}^{-1}$ of NADP ${ }^{+}, \mathrm{pH} 7.0$ ) and $0.1 \mathrm{~mL}^{\circ} 250 \mathrm{mmol} \mathrm{L}^{-1}$ 2a solution in 2-propanol. The reaction was mixed at $30^{\circ} \mathrm{C}$ and $180 \mathrm{rpm}$ for $24 \mathrm{~h}$. A $250 \mu \mathrm{L}$ aliquot of the reaction mixture was extracted with $500 \mu \mathrm{L}$ of ethyl acetate and dried with sodium sulfate. Conversion and enantiomeric excess (ee) were measured by GC-MS and GC-FID.

General procedure for deracemization by stereoinversion using immobilized $C$. albicans cells in calcium alginate beads and a ketoreductase

It was added $0.5 \mathrm{mmol}$ of substrate dissolved in $0.150 \mathrm{~mL}$ of acetone as co-solvent to a $125 \mathrm{~mL}$ Erlenmeyer flask containing $11 \mathrm{~g}$ of $C$. albicans immobilized in calcium alginate beads suspended in approximately $10 \mathrm{~mL}$ of distilled water. The flask was incubated at $30{ }^{\circ} \mathrm{C}$ and $180 \mathrm{rpm}$ in an orbital shaker, until complete oxidative kinetic resolution (OKR) was achieved, which was monitored by GC-MS (conversion) and GC-FID or HPLC (ee). Next, $1 \mathrm{~mL}$ of the reaction was collected, filtered through a $0.2 \mu \mathrm{m}$ regenerated cellulose membrane filter, and transferred to a $2 \mathrm{~mL}$ vial containing $50 \mathrm{mg}$ of dry Recycle Mix N or $25 \mathrm{mg}$ of dry Recycle Mix P, added with $100 \mu \mathrm{L}$ of 2-propanol and $4 \mathrm{mg}$ of an anti-Prelog KRED or $15 \mu \mathrm{L}$ of ADH-PL. A procedure using $2 \mathrm{mg}$ of KRED instead of $4 \mathrm{mg}$ exhibited no loss of efficiency. The reaction was mixed at $30^{\circ} \mathrm{C}$ and $180 \mathrm{rpm}$ for $24 \mathrm{~h}$. A $250 \mu \mathrm{L}$ aliquot of the reaction mixture was extracted with $500 \mu \mathrm{L}$ of ethyl acetate and dried with sodium sulfate. Conversion and ee were determined by GC-MS and GC-FID or HPLC. The process was scaled up using the total reaction volume from the OKR step $(10 \mathrm{~mL}) ; 100 \mu \mathrm{L}$ of ADH-PL was added with $1 \mathrm{~mL}$ of 2-propanol and $250 \mathrm{mg}$ of dry Recycle Mix P. The reaction was mixed at $30^{\circ} \mathrm{C}$ and $180 \mathrm{rpm}$ for $5 \mathrm{~h}$. The product was extracted with $10 \mathrm{~mL}$ ethyl acetate (3 times), dried with sodium sulfate and the solvent removed in vacuum, producing a colorless liquid, $(R)-\mathbf{1 h}, 70 \%$ yield $(0.35 \mathrm{mmol})$. MS (m/z,\%): $152\left(\mathrm{M}^{+}, 47\right), 137$ (44), 135 (20), 109 (100), 94 (30), 77 (33), 43 (17); ' ${ }^{\mathrm{H}} \mathrm{NMR}\left(400 \mathrm{MHz}, \mathrm{CDCl}_{3}\right.$ ) $\delta 1.48(\mathrm{~d}, J 6.4 \mathrm{~Hz}, 3 \mathrm{H}), 1.99(\mathrm{~s}, 1 \mathrm{H}), 3.81(\mathrm{~s}, 3 \mathrm{H}), 4.86(\mathrm{q}$, $J 6.4 \mathrm{~Hz}, 1 \mathrm{H}), 6.81(\mathrm{~m}, 1 \mathrm{H}), 6.94(\mathrm{~m}, 2 \mathrm{H}), 7.25(\mathrm{t}, J 8.0 \mathrm{~Hz}$, $1 \mathrm{H}) ;{ }^{13} \mathrm{C}$ NMR $\left(100 \mathrm{MHz}, \mathrm{CDCl}_{3}\right) \delta 25.15,55.23,70.34$, $110.92,112.90,117.70,129.55,147.62,159.79 ;[\alpha]_{\mathrm{D}}^{20}+28$ $\left(c 1.0 ; \mathrm{CHCl}_{3}\right) 91 \%$ ee $(R)$. Lit. ${ }^{46}[\alpha]_{\mathrm{D}}^{20}+29\left(c 1.0 ; \mathrm{CHCl}_{3}\right)$, $54 \%$ ee for the $(R)$-enantiomer. The ee was determined by GC-FID, with an oven temperature of $100^{\circ} \mathrm{C}$ for $3 \mathrm{~min}$, then increased to $180{ }^{\circ} \mathrm{C}$ at $1.5^{\circ} \mathrm{C} \mathrm{min}^{-1}$ and maintained constant for $10 \mathrm{~min}$; retention time: $\mathrm{t}_{R}=22.95 \mathrm{~min}[(R)$-enantiomer $]$; $\mathrm{t}_{S}=23.60 \min [(S)$-enantiomer $]$.
The substrate concentration study with $( \pm)-\mathbf{1 a}$ (35-200 $\left.\mathrm{mmol} \mathrm{L}^{-1}\right)$ was performed with $11 \mathrm{~g}$ of $C$. albicans immobilized in calcium alginate beads suspended in approximately $10 \mathrm{~mL}$ of distilled water for $1 \mathrm{~h}$. Next, $1 \mathrm{~mL}$ of the reaction was collected, filtered through a $0.2 \mu \mathrm{m}$ regenerated cellulose membrane filter, and transferred to a $2 \mathrm{~mL}$ vial containing $4 \mathrm{mg}$ of the ketoreductase KRED-P1-A04, and $25 \mathrm{mg}$ of dry Recycle Mix P. The amount of co-substrates were proportional to initial amount of 1a, 4 equiv. of acetone in the first step, and 37 equiv. of 2-propanol in the second step.

\section{Synthesis of (S)-1-(3-methoxyphenyl)ethylamine ((S)-3h)}

Triphenylphosphine (1.2 equiv.) and phthalimide (1 equiv.) were added to a solution of $(R)-\mathbf{1 h}(0.23 \mathrm{mmol})$ in $3 \mathrm{~mL}$ of dry tetrahydrofuran (THF), under nitrogen atmosphere and magnetic stirring. The solution was cooled to $0{ }^{\circ} \mathrm{C}$ and diisopropyl azodicarboxylate (DIAD, 1.2 equiv.) was added. The mixture was heated to $25^{\circ} \mathrm{C}$ and stirred for approximately $3 \mathrm{~h}$. The solvent was removed by vacuum and the product was purified by flash chromatography using a hexane/ethyl acetate gradient as the mobile phase and a Biotage Isolera Spektra One system. The protected amine was dissolved in THF $(3 \mathrm{~mL})$ and ethanol $(1 \mathrm{~mL})$, and hydrazine monohydrate $(50 \mu \mathrm{L})$ was added. The reaction was stirred at $66^{\circ} \mathrm{C}$ for $2 \mathrm{~h}$. The white suspension formed was filtered and washed with THF, and the organic solvent was evaporated in vacuum, producing a light-yellow oil, $(S)-3 \mathbf{h}$, with $60 \%$ yield $(0.14 \mathrm{mmol})$. MS $(\mathrm{m} / \mathrm{z}, \%)$ : $151\left(\mathrm{M}^{+}, 9\right), 136(100)$, 109 (16), 94 (10), 77 (8), 44 (12); ${ }^{1} \mathrm{H}$ NMR (400 MHz, $\left.\mathrm{CDCl}_{3}\right) \delta 1.39(\mathrm{~d}, 3 \mathrm{H}, J 6.8 \mathrm{~Hz}), 1.86($ br s, $2 \mathrm{H}), 3.82$ $(\mathrm{s}, 3 \mathrm{H}), 4.10(\mathrm{q}, 1 \mathrm{H}, J 6.8 \mathrm{~Hz}), 6.78(\mathrm{~m}, 1 \mathrm{H}), 6.93(\mathrm{~m}$, $2 \mathrm{H}), 7.26(\mathrm{~m}, 1 \mathrm{H}) ;{ }^{13} \mathrm{C}$ NMR $\left(100 \mathrm{MHz}, \mathrm{CDCl}_{3}\right) \delta 25.5$, 51.3, 55.2, 111.4, 112.2, 118.1, 129.5, 149.4, 159.9; $[\alpha]_{\mathrm{D}}^{20}-26.0\left(c 1.0 ; \mathrm{CHCl}_{3}\right) 91 \%$ ee $(S)$, Lit. $^{47}[\alpha]_{\mathrm{D}}^{20}-26.8$ $\left(c 1.15 ; \mathrm{CHCl}_{3}\right) \geq 96 \%$ ee for the $(S)$-enantiomer. ${ }^{47} \mathrm{In}$ order to determine the enantiomeric excess, the enantioenriched amine $(S)-\mathbf{3 h}$ was acetylated and its GC chromatogram compared to that obtained for the acetylated racemic compound. Thus, chemical acetylation was carried out using approximately $1 \mathrm{mg}$ of the amine $(S)$-3h dissolved in ethyl acetate $(1 \mathrm{~mL})$, added with $\mathrm{K}_{2} \mathrm{CO}_{3}(10 \mathrm{mg})$ and acetic anhydride $(250 \mu \mathrm{L})$. The mixture was shaken at $30{ }^{\circ} \mathrm{C}$ and $900 \mathrm{rpm}$ for $1 \mathrm{~h}$ and an aqueous $10 \mathrm{~mol} \mathrm{~L}^{-1}$ $\mathrm{NaOH}$ solution $(200 \mu \mathrm{L})$ was added. The organic layer was separated, dried with anhydrous sodium sulfate and transferred to a GC glass vial for analysis. ${ }^{48}$ Enantiomeric excess was determined by GC-FID at temperatures of $120-160{ }^{\circ} \mathrm{C}\left(0.4{ }^{\circ} \mathrm{C} \mathrm{min}-1\right)$ and $160-180{ }^{\circ} \mathrm{C}\left(5^{\circ} \mathrm{C} \mathrm{min}^{-1}\right)$ and 
kept constant for $5 \mathrm{~min} ; \mathrm{t}_{S}=91.86 \min [(S)$-enantiomer $]$; $\mathrm{t}_{R} 93.08 \min [(R)$-enantiomer].

\section{Results and Discussion}

Twenty-five commercial KREDs were screened for acetophenone (2a) reduction to determine enantioselectivity and conversion to 1-phenylethanol (1a). As shown in Table 1, all KREDs exhibited high conversion (90-98\%) in reducing 2a after 4-24 h. Twelve KREDs yielded the enantiomerically enriched alcohol 1a with $>80 \%$ ee, while five KREDs showed Prelog selectivity and produced $(S)$-1a with 96-99\% ee (Table 1, entries 2-4, 22 and 24), and seven KREDs displayed anti-Prelog selectivity producing $(R)-\mathbf{1 a}$ with 87-99\% ee (Table 1, entries 5, 6, 13, 20, 21 and 25).
The reactions were monitored for 4-24 h; based on Codexis' screening protocol, however, in some reactions $>90 \%$ conversion was detected after $1 \mathrm{~h}$ or, in certain cases, $15 \mathrm{~min}$.

Of the seven KREDs that displayed anti-Prelog activity, NADH-dependent KRED-NADH-110 converted 96\% of acetophenone (2a) to $(R)$-1a with $87 \%$ ee (Table 1 , entry 5). It was selected to couple with resting cells of C. albicans, a yeast capable of oxidizing alcohols, ${ }^{14,29,44}$ and developing a deracemization process of $( \pm)$-1a by stereoinversion. Initially, we attempted to combine C. albicans and the KRED in a one-pot process; however, this was ineffective, likely due to competition between enzymes with opposite stereoselectivity for the substrate. The yeast was immobilized in calcium alginate beads to ensure easier removal of the biocatalyst from the media

Table 1. Screening of commercial ketoreductases for reduction of acetophenone (2a)

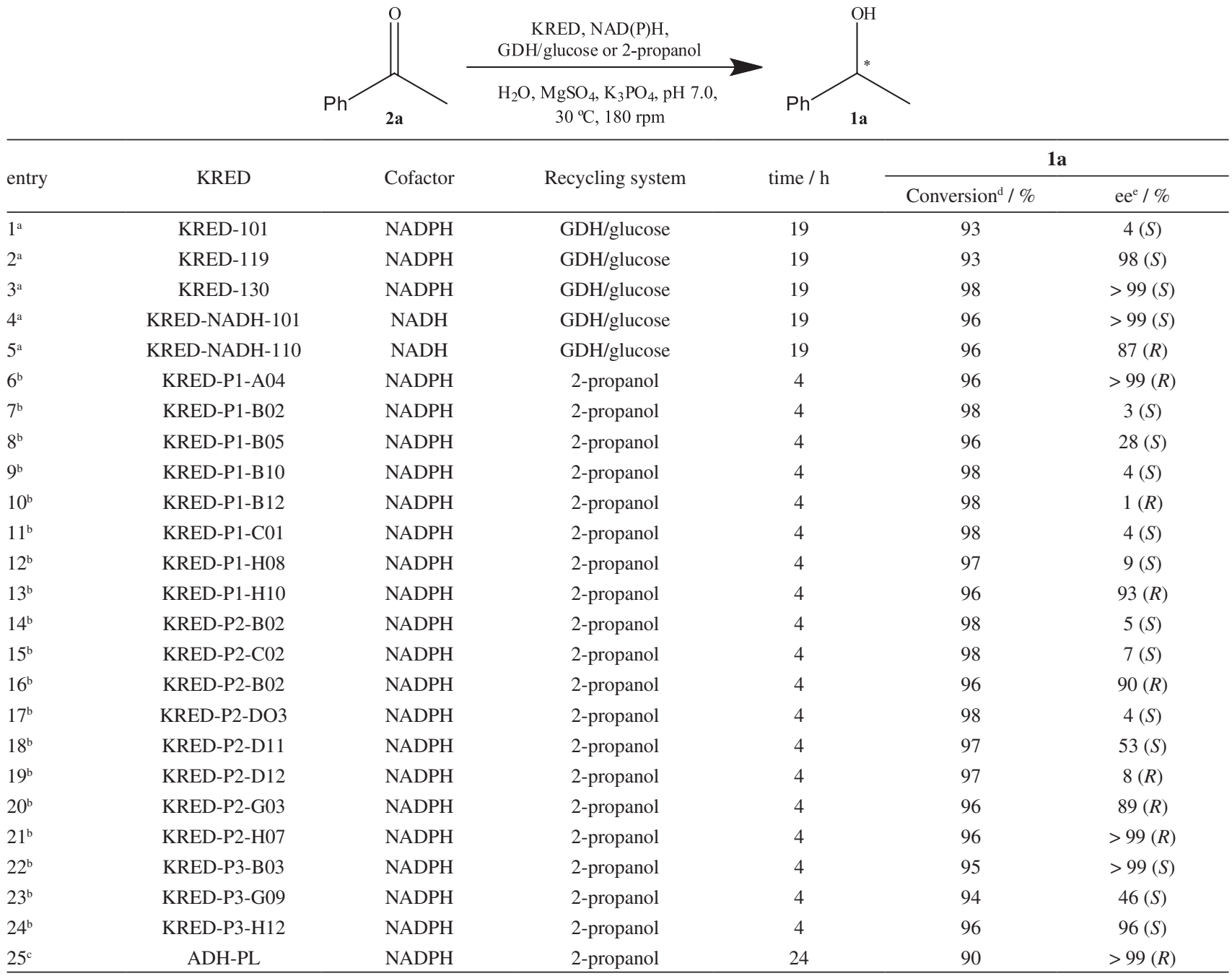

a $10 \mathrm{mg}$ of KRED, $1 \mathrm{~mL}$ of KRED Recycle Mix $\mathrm{N}$ with $50 \mathrm{mmol} \mathrm{L}^{-1}$ of $\mathbf{2 a} ;{ }^{\mathrm{b}} 10 \mathrm{mg}$ of KRED or ${ }^{\mathrm{c}} 15 \mu \mathrm{L}$ of enzyme suspension, $0.9 \mathrm{~mL}$ of KRED Recycle Mix P, $0.1 \mathrm{~mL}$ of 2-propanol, $25 \mathrm{mmol} \mathrm{L}^{-1}$ of $\mathbf{2 a}$; ${ }^{\mathrm{d}}$ conversion measured by gas chromatography-mass spectrometry (GC-MS); ${ }^{\mathrm{e} e n a n t i o m e r i c ~ e x c e s s ~(e e) ~}$ determined by gas chromatography-flame ionization detector (GC-FID). KRED: ketoreductase; NADH: nicotinamide adenine dinucleotide; ADH-PL: alcohol dehydrogenases from Parvibaculum lavamentivorans; NADPH: nicotinamide adenine dinucleotide phosphate; GDH: glucose dehydrogenase. 
after oxidation (first step). Besides there is the advantage to reuse the beads during four oxidative kinetic resolution $(\mathrm{OKR})$ cycles of $( \pm)$-1-phenylethanol (1a) without activity loss in each cycle.

Oxidative kinetic resolution (OKR) of $( \pm)$-1-arylethanols was performed using immobilized cells in Ca-alginate beads, with reaction times between $40 \mathrm{~min}$ and $16 \mathrm{~h}$. For each substrate (1a-i) the OKR time was optimized in order to obtain the best result possible. The $(R)-\mathbf{1 a - i}$ were obtained with conversion of $49-79 \%$ and $75-99 \%$ ee, as well as the corresponding ketone with conversion of $21-51 \%$ (Table 2). For ( \pm )-1a (Table 2, entry 1), OKR was reached after $40 \mathrm{~min}$ and C. albicans immobilized in Ca-alginate beads oxidized the $(S)$-enantiomer to ketone acetophenone (2a) with $51 \%$ conversion, obtaining $49 \%$ of $(R)$-1a with $94 \%$ ee. OKR of $( \pm)$-1-(4-chlorophenyl)ethanol (( \pm$)-\mathbf{1 b})$ and $( \pm)$-1-(4-bromophenyl)ethanol $( \pm)$-1d yielded the $(R)$-alcohols after a reaction of 4 and $6 \mathrm{~h}$, with 79 and $75 \%$ ee, respectively, whereas the reaction was finalized in $1 \mathrm{~h}$ for $( \pm)$-1-(4-fluorophenyl)ethanol $(( \pm)-\mathbf{1 c})$, which also exhibited a halogen in position 4 of the aromatic ring, and $(R)$-1-(4-fluorophenyl)ethanol $((R)$-1c) was obtained with $57 \%$ conversion and $90 \%$ ee (entry $2-4$, Table 2 ). The presence of a hydroxyl group in position 3 or 4 of the aromatic ring (entry 7 and 9, Table 2) promoted a significant increase in ORK time, from $40 \mathrm{~min}$ to $16 \mathrm{~h}$.
A sequential process was proposed for deracemization via stereoinversion: efficient OKR of $( \pm)-\mathbf{1 a}(0.5 \mathrm{mmol})$ was observed after 40 min with $C$. albicans cells immobilized in calcium alginate beads: $51 \%$ acetophenone (2a) and $49 \%$ $(R)$-1-phenylethanol ( $(R)-1 a)$, with $94 \%$ ee. Subsequently, the beads were removed and KRED-NADH-110, NAD $(\mathrm{P})^{+}$, $\mathrm{D}$-glucose, and GDH were dispersed in $1 \mathrm{~mL}$ of the reaction mixture. After 15 min of reduction, $90 \%$ of $(R)$-1a with $91 \%$ ee was obtained, resulting in successful deracemization in less than $1 \mathrm{~h}$ (Figure 2). The anti-Prelog ketoreductases KRED-P1-H10, KRED-P2-H07, KRED-P1-A04, KRED-P2-C11 and ADH-PL, which are dependent of NADPH (nicotinamide adenine dinucleotide phosphate) cofactor, were also coupled with the immobilized yeast cells. In this process, 2-propanol was used to regenerate the NADPH cofactor, enabling efficient deracemization of $( \pm)$-1-arylethanols and yielding $(R)$-enantiomers (Table 3 ).

The deracemization process was efficient and produced $(R)$-1-arylethanols $((R)-\mathbf{1 a}-\mathbf{i})$ with excellent conversion (up to $99 \%$ ) and high ee (up to $>99 \%$ ) in less than $20 \mathrm{~h}$ (oxidative and reductive steps). However, for $\mathbf{1 f}$ and $\mathbf{1 g}$, successful OKR with $C$. albicans cells immobilized in Ca-alginate beads (Table 2, entries 6 and 7) was observed in the first step, but no or low selective reduction of the respective ketones (2f and $\mathbf{2 g}$ ) was detected (second step) with the KREDs studied after $24 \mathrm{~h}$ (Table 3, entries 15 and 16). The entire deracemization process of

Table 2. Oxidative kinetic resolution (OKR) of $0.50 \mathrm{mmol}$ of 1 -arylethanol with $C$. albicans cells immobilized in calcium alginate beads

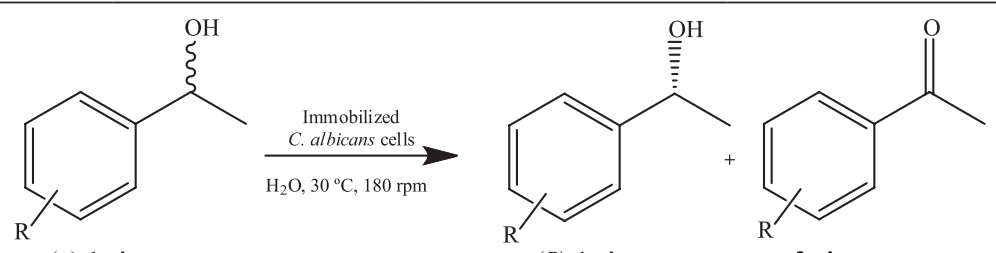

$( \pm)-\mathbf{a}-\mathbf{i}$
$(R)-\mathbf{1 a}-\mathbf{i}$

2a-i

\begin{tabular}{|c|c|c|c|c|c|}
\hline \multirow{2}{*}{ entry $^{a}$} & \multirow{2}{*}{ Substrate } & \multirow{2}{*}{$\mathrm{R}$} & \multirow{2}{*}{ time / h } & \multicolumn{2}{|c|}{ Alcohol } \\
\hline & & & & Conversion $^{\mathrm{b}} / \%$ & $\mathrm{ee}^{\mathrm{c} / \%}$ \\
\hline 1 & $( \pm)-1 a$ & $\mathrm{H}$ & 0.67 & 49 & $94(R)^{\mathrm{c}}$ \\
\hline 2 & $( \pm)-1 b$ & 4-Cl & 4 & 73 & $79(R)^{\mathrm{c}}$ \\
\hline 3 & $( \pm)-1 c$ & $4-\mathrm{F}$ & 1 & 57 & $90(R)^{\mathrm{c}}$ \\
\hline 4 & $( \pm)-1 d$ & 4-Br & 6 & 79 & $75(R)^{\mathrm{c}}$ \\
\hline 5 & $( \pm)-1 e$ & 4-Me & 1 & 55 & $93(R)^{\mathrm{c}}$ \\
\hline 6 & $( \pm)-1 f$ & 4-OMe & 2 & 49 & $>99(R)$ \\
\hline 7 & $( \pm)-1 g$ & $4-\mathrm{OH}$ & 16 & 49 & $>99(R)$ \\
\hline 8 & $( \pm)-1 h$ & 3-OMe & 2 & 57 & $93(R)^{\mathrm{c}}$ \\
\hline 9 & $( \pm)-1 \mathbf{i}$ & $3-\mathrm{OH}$ & 16 & 53 & $96(R)^{\mathrm{d}}$ \\
\hline
\end{tabular}

${ }^{\mathrm{a}} 0.5 \mathrm{mmol}$ of $1 \mathrm{a}-\mathrm{i}, 0.150 \mathrm{~mL}$ of acetone, $11 \mathrm{~g}$ of $C$. albicans immobilized in calcium alginate beads, $10 \mathrm{~mL}$ of $\mathrm{H}_{2} \mathrm{O}$. The reactions were mixed at $30{ }^{\circ} \mathrm{C}$ and $180 \mathrm{rpm}$; ${ }^{\mathrm{b}}$ conversion monitored by gas chromatography-mass spectrometry (GC-MS); 'enantiomeric excess (ee) determined by gas chromatography-flame ionization detector (GC-FID); dee was determined by HPLC. 


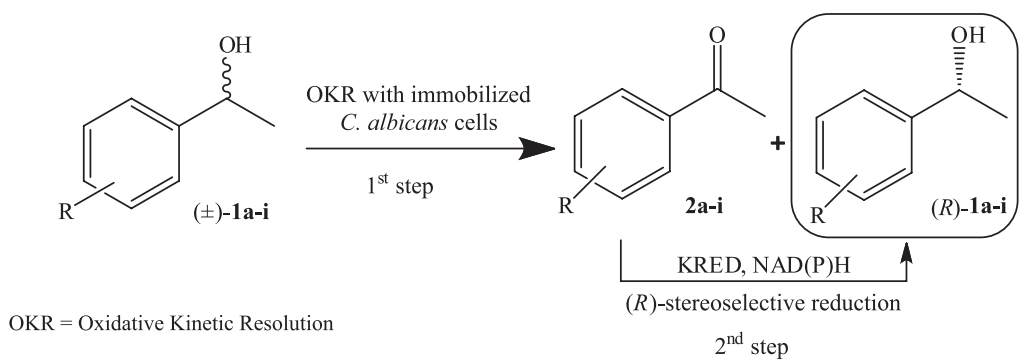

Figure 2. Deracemization by stereoinversion of ( \pm )-1-arylethanols using immobilized C. albicans cells in calcium alginate beads and an anti-Prelog KRED.

Table 3. Deracemization of ( \pm -1-arylethanols by stereoinversion using immobilized $C$. albicans cells in calcium alginate beads and a commercial KRED

\begin{tabular}{|c|c|c|c|c|c|c|}
\hline \multirow{2}{*}{ entry $^{\mathrm{a}}$} & \multirow{2}{*}{ Substrate } & \multirow{2}{*}{$\mathrm{R}$} & \multirow{2}{*}{ Reduction catalyst } & \multirow{2}{*}{ time / h } & \multicolumn{2}{|c|}{ 1a-i } \\
\hline & & & & & Conversion $/ \%$ & ee $/ \%$ \\
\hline $1^{\mathrm{b}}$ & 1a & $\mathrm{H}$ & KRED-P1-A04 & 2 & 90 & $97(R)^{\mathrm{f}}$ \\
\hline $2^{\mathrm{b}}$ & & & KRED-P1-H10 & 2 & 98 & $92(R)^{\mathrm{f}}$ \\
\hline $3^{\mathrm{d}}$ & & & ADH-PL & 9 & 92 & $95(R)^{\mathrm{f}}$ \\
\hline $4^{\mathrm{b}}$ & $1 \mathbf{b}$ & $4-\mathrm{Cl}$ & KRED-P2-C11 & 5 & $>99$ & $82(R)^{\mathrm{f}}$ \\
\hline $5^{\mathrm{b}}$ & & & KRED-P2-H07 & 5 & $>99$ & $83(R)^{\mathrm{f}}$ \\
\hline $6^{c}$ & & & ADH-PL & 12 & $>99$ & $84(R)^{\mathrm{f}}$ \\
\hline $7^{\mathrm{b}}$ & $1 \mathrm{c}$ & $4-\mathrm{F}$ & KRED-P1-A04 & 3 & 90 & $94(R)^{\mathrm{f}}$ \\
\hline $8^{\mathrm{b}}$ & & & KRED-P2-C11 & 3 & 92 & $95(R)^{\mathrm{f}}$ \\
\hline $9^{c}$ & & & ADH-PL & 7 & 91 & $95(R)^{\mathrm{f}}$ \\
\hline $10^{\mathrm{b}}$ & 1d & $4-\mathrm{Br}$ & KRED-P1-A04 & 19 & $>99$ & $89(R)^{\mathrm{f}}$ \\
\hline $11^{\mathrm{b}}$ & & & KRED-P2-C11 & 7 & $>99$ & $84(R)^{\mathrm{f}}$ \\
\hline $12^{\mathrm{c}}$ & & & ADH-PL & 14 & $>99$ & $79(R)^{\mathrm{f}}$ \\
\hline $13^{\mathrm{b}}$ & 1e & $4-\mathrm{CH}_{3}$ & KRED-P2-C11 & 2 & 96 & $96(R)^{\mathrm{f}}$ \\
\hline $14^{\mathrm{b}}$ & & & KRED-P2-H07 & 2 & 97 & $95(R)^{\mathrm{f}}$ \\
\hline $15^{\mathrm{b}}$ & 1f & $4-\mathrm{OCH}_{3}$ & KRED-P1-A04 & 24 & 50 & $>99(R)^{\mathrm{f}}$ \\
\hline $16^{c}$ & $1 \mathrm{~g}$ & $4-\mathrm{OH}$ & ADH-PL & 40 & 52 & $87(R)^{\mathrm{f}}$ \\
\hline $17^{\mathrm{b}}$ & $1 \mathrm{~h}$ & 3-OMe & KRED-P1-A04 & 19 & 95 & $93(R)^{\mathrm{f}}$ \\
\hline $18^{\mathrm{b}}$ & & & KRED-P2-H07 & 3 & 99 & $93(R)^{\mathrm{f}}$ \\
\hline $19^{d}$ & & & ADH-PL & 10 & 96 & $91(R)^{\mathrm{f}}$ \\
\hline $20^{\mathrm{b}}$ & $\mathbf{1 i}$ & $3-\mathrm{OH}$ & KRED-P1-A04 & 17 & 94 & $96(R)^{\mathrm{g}}$ \\
\hline $21^{\mathrm{b}}$ & & & KRED-P2-H07 & 17 & 94 & $96(R)^{\mathrm{g}}$ \\
\hline
\end{tabular}

${ }^{\mathrm{a}} 1^{\text {st }}$ step: $0.5 \mathrm{mmol}$ of $\mathbf{1 a - i}, 0.150 \mathrm{~mL}$ of acetone, $11 \mathrm{~g}$ of immobilized C. albicans, $10 \mathrm{~mL}$ of $\mathrm{H}_{2} \mathrm{O} ; 2^{\text {nd }}$ step: $1 \mathrm{~mL}$ of the reaction, $25 \mathrm{mg}$ of dry Recycle Mix P, $0.100 \mathrm{~mL}$ of 2-propanol; ${ }^{b} 4 \mathrm{mg}$ of KRED or ${ }^{\mathrm{c}} 15 \mu \mathrm{L}$ of ADH-PL; ${ }^{\mathrm{d}} 10 \mathrm{~mL}$ of oxidative kinetic resolution (OKR) (first step), $0.100 \mathrm{~mL}$ of ADH-PL, $1 \mathrm{~mL}$ of 2-propanol and $250 \mathrm{mg}$ of dry Recycle Mix P; ${ }^{\mathrm{e}}$ conversion monitored by gas chromatography-mass spectrometry (GC-MS); ${ }^{\mathrm{f}} \mathrm{enantiomeric} \mathrm{excess} \mathrm{(ee)}$ determined by gas chromatography-flame ionization detector (GC-FID); gee determined by HPLC. KRED: ketoreductase; ADH-PL: alcohol dehydrogenases from Parvibaculum lavamentivorans.

$( \pm)-1$-phenylethanol (( \pm$)-1 \mathbf{a})$ lasted about $2 \mathrm{~h}$, including 40 min of OKR using immobilized $C$. albicans cells and $1 \mathrm{~h}$ of reduction with KRED-P1-A04 or KRED-P1-H10 (entries 1 and 2, Table 3), yielding ( $R$ )-1-phenylethanol $((R)$-1a) with $90-98 \%$ conversion and $92-97 \%$ ee. Reduction of acetophenone (2a) with ADH-PL was slower, lasting $8 \mathrm{~h}$ (entry 3 , Table 3 ). In this case, the complete procedure took $9 \mathrm{~h}$ and provided $92 \%(R)-1 \mathrm{a}$ with $95 \%$ ee.

The process was scaled up (10 times) with $( \pm)$-1a and $( \pm)$-1h using the ADH-PL. Reproducibility of the results was maintained (entries 3 and 19, Table 3), leading to $(R)-\mathbf{1 a}$ and $(R)-\mathbf{1 h}$ with excellent conversion (above $90 \%$ ), $91-95 \%$ ee and $70 \%$ yield of $(R)-\mathbf{1 h}$ starting from $0.5 \mathrm{mmol}$ of racemate $( \pm)-\mathbf{1 h}$.

Substrate concentration was evaluated from 35-200 mmol L-1 of ( \pm )-1a, using C. albicans cells immobilized in Ca-alginate beads and $4 \mathrm{mg}$ of KRED-P1-A04 after $2 \mathrm{~h}$ (Table 4). The process demonstrated to be efficient for concentration until $110 \mathrm{mmol} \mathrm{L}^{-1}$, furnishing $(R)-1$ a $(91-94 \%, 90-94 \%$ ee, entries 1-4, 
Table 4. Study of the substrate concentration in deracemization of $( \pm)-\mathbf{1 a}$, using $C$. albicans cells immobilized in Ca-alginate beads and $4 \mathrm{mg}$ of KRED-P1-A04 after $2 \mathrm{~h}$

\begin{tabular}{|c|c|c|c|}
\hline \multirow{2}{*}{ entry $^{a}$} & \multirow{2}{*}{$\begin{array}{l}\text { Substrate concentration } \\
(( \pm)-\mathbf{1 a}) /\left(\mathrm{mmol} \mathrm{L}^{-1}\right)\end{array}$} & \multicolumn{2}{|l|}{$1 \mathrm{a}$} \\
\hline & & Conversion $^{\mathrm{b}} / \%$ & $\mathrm{ee}^{\mathrm{c} / \%}$ \\
\hline 1 & 35 & 94 & $93(R)$ \\
\hline 2 & 55 & 92 & $94(R)$ \\
\hline 3 & 82 & 92 & $93(R)$ \\
\hline 4 & 110 & 91 & $90(R)$ \\
\hline 5 & 150 & 92 & $79(R)$ \\
\hline 6 & 200 & 75 & $40(R)$ \\
\hline
\end{tabular}

${ }^{\mathrm{a}}{ }^{\text {st }}$ step: ( \pm )-1a 35-200 $\mathrm{mmol} \mathrm{L}^{-1}, 4$ equiv. of acetone, $11 \mathrm{~g}$ of immobilized C. albicans, $10 \mathrm{~mL}$ of $\mathrm{H}_{2} \mathrm{O}, 1 \mathrm{~h} ; 2^{\text {nd }}$ step: $1 \mathrm{~mL}$ of the reaction, $25 \mathrm{mg}$ of dry Recycle Mix P, 37 equiv. of 2-propanol, 4 mg of KRED-P1-A04, $1 \mathrm{~h}$; ${ }^{\mathrm{b}}$ conversion monitored by gas chromatography-mass spectrometry (GC-MS); 'enantiomeric excess (ee) determined by gas chromatographyflame ionization detector (GC-FID).

Table 4). Similar processes were proposed to deracemize secondary alcohols such as 2-octanol, sulcatol, 2-decanol and 1-phenylethanol, with 30-80 $\mathrm{mmol} \mathrm{L}^{-1}$ substrate concentration. ${ }^{1,36}$ Compared to the procedure developed here, we could successfully deracemize $110 \mathrm{mmol} \mathrm{L}^{-1}$ of $( \pm)$-1a and other $( \pm)$-1-arylethanols into the $(R)$-enantiomer with high conversion and ee, using commercially available ketoreductases and immobilized yeast.

As an example of the applicability of this procedure, it was obtained $(R)-\mathbf{1 h}$ from $( \pm)-1-(3-$ methoxyphenyl)ethanol $(( \pm)$-1h) with $70 \%$ yield and $91 \%$ ee, which was used to prepare $(S)$-1-(3-methoxyphenyl)ethylamine $((S)-3 \mathbf{h})$, a key intermediate of $(S)$-rivastigmine synthesis that is used to treat Parkinson's and Alzheimer's diseases. ${ }^{49}$ Synthesis of $(S)-3 h$ consisted of two steps: a Mitsunobu reaction, with substitution of the hydroxyl group for phthalimide and configuration inversion, followed by phthalimide hydrolysis with hydrazine, yielding $60 \%(S)$-3h with $91 \%$ ee. The preparation of $(S)-\mathbf{3 h}$ from $( \pm)-\mathbf{1 h}$ is shown in Figure 3.
Methodologies with a chemoenzymatic or biocatalytic step have been reported in the preparation of $(S)$-3h due to the importance of this compound in organic synthesis; $;, 48,50,51$ however, none applied deracemization via stereoinversion step with substrate concentration above $100 \mathrm{mmol} \mathrm{L}^{-1}$.

\section{Conclusions}

This study demonstrated the significant oxidative potential of $C$. albicans CCT 0776 as an enantioselective catalyst for the oxidation of secondary alcohols, especially $( \pm)$-1-arylethanols, and its application in oxidationreduction sequences for deracemization via stereoinversion of those compounds coupled with commercially available ketoreductases, yielding $(R)$-1-arylethanols, $(R)$-1a-e and $(R)-\mathbf{1 h}-\mathbf{i}$, with $90-99 \%$ conversion and $79-99 \%$ ee, after 2-19 h. As an example of the applicability of this procedure, we obtained $(R)$-1h from $( \pm)$-1-(3-methoxyphenyl)ethanol $(( \pm)-\mathbf{1 h})$ with $70 \%$ yield and $91 \%$ ee, which was used to prepare the $(S)$-rivastigmine precursor $(S)$-1-(3-methoxyphenyl)ethylamine $((S)-3 h)$, with $60 \%$ yield and $91 \%$ ee. These results represent a useful asymmetric green methodology applicable in organic synthesis, since the immobilization of biocatalyst provided the reuse of the catalyst besides the possibility to increase the substrate concentration above $100 \mathrm{mmol} \mathrm{L}^{-1}$.

\section{Supplementary Information}

Supplementary data are available free of charge at http://jbcs.sbq.org.br as PDF file.

\section{Acknowledgments}

The authors are grateful to FAPESP (grant 2016/12074-7, São Paulo State Foundation) and CNPq (grant 301212/2010-4) for their generous financial support.

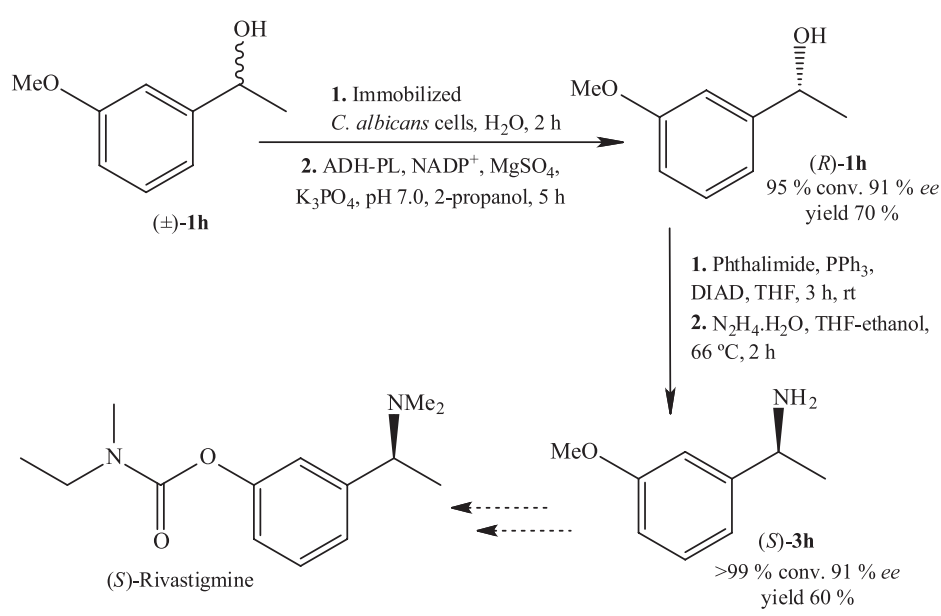

Figure 3. Synthesis of (S)-1-(3-methoxyphenyl)ethylamine ((S)-3h) from ( \pm )-1-(3-methoxyphenyl)ethanol (( \pm$)-\mathbf{1 h})$. 


\section{References}

1. Paul, C. E.; Lavandera, I.; Gotor-Fernandez, V.; Kroutil, W.; Gotor, V.; Chem CatChem 2013, 5, 3875.

2. Kohler, V.; Turner, N. J.; Chem. Commun. 2015, 51, 450.

3. Both, P.; Busch, H.; Kelly, P. P.; Mutti, F. G.; Turner, N. J.; Flitsch, S. L.; Angew. Chem., Int. Ed. 2016, 55, 1511.

4. Paula, B. R. S.; Zampieri, D.; Rodrigues, J. A. R.; Moran, P. J. S.; Adv. Synth. Catal. 2016, 358, 3555.

5. Bertolotti, M.; Brenna, E.; Crotti, M.; Gatti, F. G.; Monti, D.; Parmeggiani, F.; Santangelo, S.; ChemCatChem 2016, 8, 577.

6. Mangas-Sanchez, J.; Rodriguez-Mata, M.; Busto, E.; GotorFernandez, V.; Gotor, V.; J. Org. Chem. 2009, 74, 5304.

7. Brieva, R.; Crich, J. Z.; Sih, C. J.; J. Org. Chem. 1993, 58, 1068.

8. Chenevert, R.; Fortier, G.; Chem. Lett. 1991, 20, 1603.

9. Banfi, L.; Cascio, G.; Ghiron, C.; Guanti, G.; Manghisi, E.; Narisano, E.; Riva, R.; Tetrahedron 1994, 50, 11983.

10. Swaren, P.; Massova, I.; Bellettini, J. R.; Bulychev, A.; Maveyraud, L.; Kotra, L. P.; Miller, M. J.; Mobashery, S.; Samama, J.-P.; J. Am. Chem. Soc. 1999, 121, 5353.

11. Guaragna, A.; De, N. M.; Pedatella, S.; Palumbo, G.; Tetrahedron: Asymmetry 2006, 17, 2839.

12. Zhou, B. N.; Gopalan, A. S.; VanMiddlesworth, F.; Shieh, W. R.; Sih, C. J.; J. Am. Chem. Soc. 1983, 105, 5925.

13. Mann, S. J.; J. Am. Soc. Hypertens. 2017, 11, 54.

14. Nasário, F. D.; Cazetta, T.; Moran, P. J. S.; Rodrigues, J. A. R.; Tetrahedron: Asymmetry 2016, 27, 404.

15. Liu, Y.; Guo, C.; Liu, C.-Z.; J. Mol. Catal. B: Enzym. 2014, 101, 23.

16. Kozyra, K.; Brzezińska-Rodak, M.; Klimek-Ochab, M.; Żymańczyk-Duda, E.; J. Mol. Catal. B: Enzym. 2013, 91, 32.

17. Leisch, H.; Grosse, S.; Iwaki, H.; Hasegawa, Y.; Lau, P. C. K.; Can. J. Chem. 2012, 90, 39.

18. Silva, C. R.; Souza, J. C.; Araújo, L. S.; Kagohara, E.; Garcia, T. P.; Pelizzari, V. H.; Andrade, L. H.; J. Mol. Catal. B: Enzym. 2012, 83, 23.

19. Deasy, R. E.; Brossat, M.; Moody, T. S.; Maguire, A. R.; Tetrahedron: Asymmetry 2011, 22, 47.

20. Martins, R. S.; Zampieri, D. S.; Rodrigues, J. A. R.; Carvalho, P. O.; Moran, P. J. S.; ChemCatChem 2011, 3, 1469.

21. Conceição, G. J. A.; Moran, P. J. S.; Rodrigues, J. A. R.; Tetrahedron: Asymmetry 2003, 14, 43.

22. Nakamura, K.; Yamanaka, R.; Matsuda, T.; Harada, T.; Tetrahedron: Asymmetry 2003, 14, 2659.

23. Yadav, J. S.; Nanda, S.; Reddy, P. T.; Rao, A. B.; J. Org. Chem. 2002, 67, 3900.

24. Diaz-Rodriguez, A.; Lavandera, I.; Gotor, V.; Curr. Green Chem. 2015, 2, 192.

25. Rudroff, F.; Mihovilovic, M. D.; Gröger, H.; Snajdrova, R.; Iding, H.; Bornscheuer, U. T.; Nat. Catal. 2018, 1, 12.

26. Torrelo, G.; Hanefeld, U.; Hollmann, F.; Catal. Lett. 2015, 145 , 309.
27. Alsafadi, D.; Alsalman, S.; Paradisi, F.; Org. Biomol. Chem. 2017, 15, 9169.

28. Mantovani, S. M.; Angolini, C. F. F.; Marsaioli, A. J.; Tetrahedron: Asymmetry 2009, 20, 2635.

29. Cazetta, T.; Moran, P. J. S.; Rodrigues, J. A. R.; J. Mol. Catal. B: Enzym. 2014, 109, 178.

30. Lunardi, I.; Cazetta, T.; Conceição, G. J. A.; Moran, P. J. S.; Rodrigues, J. A. R.; Adv. Synth. Catal. 2007, 349, 925.

31. Cazetta, T.; Lunardi, I.; Conceicão, G. J. A.; Moran, P. J. S.; Rodrigues, J. A. R.; Tetrahedron: Asymmetry 2007, 18, 2030.

32. Chen, L. S.; Mantovani, S. M.; de Oliveira, L. G.; Duarte, M. C. T.; Marsaioli, A. J.; J. Mol. Catal. B: Enzym. 2008, 54, 50.

33. Li, Y.-L.; Xu, J.-H.; Xu, Y.; J. Mol. Catal. B: Enzym. 2010, 64, 48.

34. Molinari, F.; Brenna, O.; Valenti, M.; Aragozzini, F.; Enzyme Microb. Technol. 1996, 19, 551.

35. Takahashi, E.; Nakamichi, K.; Furui, M.; J. Ferment. Bioeng. 1995, 80, 247.

36. Voss, C. V.; Gruber, C. C.; Kroutil, W.; Angew. Chem., Int. Ed. 2008, 47, 741.

37. Mendez-Sanchez, D.; Mangas-Sanchez, J.; Lavandera, I.; Gotor, V.; Gotor-Fernandez, V.; ChemCatChem 2015, 7, 4016.

38. Voss, C. V.; Gruber, C. C.; Faber, K.; Knaus, T.; Macheroux, P.; Kroutil, W.; J. Am. Chem. Soc. 2008, 130, 13969.

39. Karume, I.; Takahashi, M.; Hamdan, S. M.; Musa, M. M.; ChemCatChem 2016, 8, 1459.

40. Gruber, C. C.; Lavandera, I.; Faber, K.; Kroutil, W.; Adv. Synth. Catal. 2006, 348, 1789.

41. Turner, N. J.; Chem. Rev. 2011, 111, 4073.

42. Cardus, G. J.; Carnell, A. J.; Trauthwein, H.; Riermeir, T.; Tetrahedron: Asymmetry 2004, 15, 239.

43. Magallanes-Noguera, C.; Ferrari, M. M.; Kurina-Sanz, M.; Orden, A. A.; J. Biotechnol. 2012, 160, 189.

44. Chadha, A.; Venkataraman, S.; Preetha, R.; Padhi, S. K.; Bioorg. Chem. 2016, 68, 187.

45. Kandiah, N.; Pai, M.-C.; Senanarong, V.; Looi, I.; Ampil, E.; Park, K. W.; Karanam, A. K.; Christopher, S.; Clin. Interventions Aging 2017, 12, 697.

46. Inagaki, T.; Ito, A.; Ito, J.; Nishiyama, H.; Angew. Chem., Int. Ed. 2010, 49, 9384.

47. Lamblin, M.; Couture, A.; Deniau, E.; Grandclaudon, P.; Tetrahedron: Asymmetry 2008, 19, 111.

48. Martinez-Montero, L.; Gotor, V.; Gotor-Fernandez, V.; Lavandera, I.; Green Chem. 2017, 19, 474.

49. Spencer, C. M.; Noble, S.; Drugs Aging 1998, 13, 391.

50. Uthoff, F.; Sato, H.; Groeger, H.; ChemCatChem 2017, 9, 555.

51. Fuchs, M.; Koszelewski, D.; Tauber, K.; Kroutil, W.; Faber, K.; Chem. Commun. 2010, 46, 5500.

Submitted: July 12, 2018

Published online: October 11, 2018 